\title{
THE INFLUENCE OF INDEPENDENT BOARD OF COMMISSIONERS, AUDIT COMMITTEE, AND AUDIT QUALITY ON TAX AVOIDANCE
}

\author{
Yuliana Gunawan', Yunita Christy ${ }^{2}, \mathrm{Se} \mathrm{Tin}^{3}$, Livia Jonathan ${ }^{4}$ \\ ${ }^{1,2,3,4}$ Universitas Kristen Maranatha, Bandung
}

\begin{abstract}
This study is aimed to examine and analyze the influence of Independent Board of Commissioners, Audit Committee, and Audit Quality on Tax Avoidance. The sample in this study is mining companies listing on the Indonesia Stock Exchange in the period 2017-2019. Researchers are interested in doing this study because the mining sector provides high economic value to the country but the tax contribution from this sector is still minimal. The analysis used the multiple linear regression technique using the SPSS 20.0 program. The results of this study indicate that partially independent board of commissioners and audit quality have an effect on tax avoidance, however the audit committee has no partial effect on tax avoidance. Simultaneously the independent board of commissioners, audit committee and audir quality have an effect on tax avoidance. This study is expected to provide benefits for the government, companies and for future researchers.

$\begin{array}{ll}\text { Keywords } & \text { : Independent Board of Commissioners; Audit Committee; Audit } \\ & \text { Quality;Tax Avoidance } \\ \text { Correspondence to } & \text { : yuliana_ok99@yahoo.com }\end{array}$
\end{abstract}

\section{ABSTRAK}

Studi ini bertujuan untuk memverifikasi dan menganalisis pengaruh Dewan Komisaris Independen, Komite Audit, dan Kualitas Audit terhadap Penghindaran Pajak. Pengambilan contoh dalam penelitian ini adalah perusahaan yang bergerak dibidang pengambilan sumber daya alam/pertambangan yang listing di Bursa Efek Indonesia periode 2017-2019. Peneliti tertarik melakukan penelitian ini karena sektor pertambangan memberikan nilai ekonomi yang tinggi bagi negara namun kontribusi pajak dari sektor tersebut masih minim. Teknik penguraian data yang digunakan adalah regresi linier berganda dengan menggunakan program SPSS 20.0. Hasil dari studi ini menunjukkan bahwa secara parsial Dewan Komisaris Independen dan Kualitas Auditr berpengaruh terhadap Penghindaran Pajak, sedangkan Komite Audit tidak berpengaruh terhadap Penghindaran Pajak. Secara simultan Dewan Komisaris Independen, Komite Audit dan Kualitas Audit berpengaruh terhadap Penghindaran Pajak. Studi ini diharapkan dapat memberikan kontribusi bagi perusahaan dan peneliti selanjutnya.
Kata kunci $\quad$ : Dewan Komisaris Independen; Komite Audit; Kualitas Audit; Penghindaran Pajak

\section{Riwayat Artikel:}

$\begin{array}{ll}\text { Received } & : 23 \text { November } 2020 \\ \text { Revised } & : 07 \text { Desember } 2020 \\ \text { Accepted } & : 11 \text { Januari } 2021\end{array}$




\section{INTRODUCTION}

One of the country's biggest sources of incomes is the tax sector; therefore, the government formulates a regulation that manages the taxation in Indonesia in order to maximize the tax potential received by the state. A tax is a mandatory contribution to be paid for by an individual or a body to the country, which is compelling in accordance with the law and is without any direct rewards (UU No.28, 2007).

In accounting, a tax is an expense that reduces the net profit; this is contrary to the objectives of a business entity that wants to have a large profit. These factors that make the tax as a burden and obligation may trigger tax avoidance. Tax avoidance is oftentimes related to the tax planning, in the sense that both use legal means to decrease or eliminatefully the obligation to pay tax. The tax avoidance by a company does not happen coincidentally; on the contrary, it has been planned strategically (Hanafi \& Harto, 2014)

Corporate governance plays several roles, and one of them is as a tax avoidance supervisor. Coporate governance determines the direction of the company in accordance with the head of the company itself. The characteristics of the head of a company influences the decisions made in the company, including the decisions regarding tax avoidance.

The practice of tax avoidance in a company is greatly influenced by the corporate governance factor. Studies have been done to see how corporate governance influences tax avoidance. An empirical result by (Winata, 2014) proves that corporate governance which is represented by the independent commissioners and audit committee plays a role on tax avoidance. Meanwhile, the proxy of audit quality and institutional ownership does not influence tax avoidance. This is different from (Alviyani et al., 2016) study that shows that institutional ownership has an effect on tax avoidance. Another research, conducted by (Sandy \& Lukvirman, 2015), shows a different result, which shows that independent commissioners do not affect tax avoidance. This empirical finding is in contrast to the findings with (Alviyani et al., 2016) and (Winata, 2014) research results that claim the significance effect of the independent board of commissioners on tax avoidance. (Annisa \& Kurniasih, 2012) applies audit quality as a variable in their research, which results show the connection between the qualities of the audit on tax avoidance. However, the result is different fromones that are found in (Sandy \& Lukvirman, 2015) research which shows no significant effect on the audit quality on tax avoidance.

Mining companies are chosen based on their business activities which mostly involve taxations. Mining industry is an industry with a high economic value for the government. Based on the data from the Central Bureau of Statistics (BPS) between years 2014 to 2018, coal and lignite mining industries contribute around $2.3 \%$ on average on the gross domestic products (PDB) per year, or equivalent to $\mathrm{Rp}$ 235 trillions. Coals are the second largest contributor from the extractive sector after oil, gas, and geothermal. However, despite the high economic value of the coal industry, the data taken from the Ministry of Finance shows that the industry contributes very little on taxes. The tax ratio from the mineral and coal mining sector in 2016 was only as high as $3.9 \%$ while the national tax ratio in the same year was $10.4 \%$. The low tax ratio cannot be separated from the problem of tax avoidance by coal business actors. The Ministry of Finance records that the number of taxpayers holding mineral and coal business license that does not report their annual tax return (SPT) is higher than those who do. It is worth noting that even the taxpayers who do report their tax return may potentially not report it according to the facts in the field. Moreover, there are some who report their tax returns correctly but in reality the report is the result of tax avoidance and tax savings.

This study examines whether corporate governance is able to influence tax avoidance. Corporate governance is used as it is predicted to have influence on tax avoidance. Corporate governance itself is divided into three proxies: audit committee, and audit quality, independent commissioners. 
(Aras \& Crowther, 2010) suggests that the procedure of good corporate government is categorized into external and internal methods. The internal method holds control from inside the company (board of directors, annual general meetings, board of commissioners, meetings of directors). On the other hand, the external method takes control from outside the company (market control). In this study, corporate governance includes the Audit Committee, Independent Board of Commissioners, and Audit Quality.

The existence of the independent commissioners will create a more independent and objective climate and increase fairness in the company as one of the major principles in upholding the rights of less than half shareholders and other participant.

An independent commissioner has the rights to give a different opinion from other board members and to have their opinion recorded in the Minutes of the Board of Commissioners Meeting. In addition, if the opinion is materially different, it has to be recorded in the Annual Report(Subrata, 2020).

(Arief, 2009), in (Hery, 2017), states that the function of independent commissioners is to balance the decision(s) made by the board of commissioners. The following is the formula to calculate the independent board of commissioner

$\underline{\text { Independent Board of Commissioners }}$ Board of Commissioners

(1)

The audit committee have responsible for doing the necessary supervision and examination on the implementation of the function of the directors in managing a company. This committee consists of three people and one of them is to have an expertise in either accounting or finance.

The establishment of the audit committee is facultive, which means it may be established and not imperative (compulsory); hence, it is entirely up to the policies and considerations of the Board of Commissioners. However, issuers or public corporation are required to have an audit committee.
According to (Oktadella \& ZULAIKHA, 2011), several reasons a company uses the service of the Public Accounting Firm Big Four are: The shareholders wants the Big Four firm; The company wants to gain the trust of the investors or the support from the capital market; The Big Four firm has strong financial resources to keep their job; Public companies are required to use the Big Four firm. The Big Four firm is also guaranteed in terms of quality due to the number and variety of clients that the Public Accounting Firt (KAP) handles, the variety of services offered, the a wide geographic coverage including international affiliations and the number of audit staff in a KAP.

(Zain, 2008) claims that tax avoidance is an attempt to reduce the tax burden by using actual option which are acceptable to the tax authorities. This is in line with (Pohan, 2016), who states that tax avoidance is an endeavor done by the taxpayers to keep away from paying the tax by legal and safe means as they do not contradict the taxation regulations; the methods and techniques used in this are mostly taking advantage of the grey area in the law and taxation regulations and they are used to minimize the amount of the tax owed.

Tax avoidance is calculated using the Effective Tax Rate (ETR). The formula is as follows:

Effective Tax Rate (ETR)=income tax expense Income before tax (2)

A previous research by (Alviyani et al., 2016) proves that the independent boards of commissioners had a significant result on tax avoidance. Stand on the above explanation, the hypothesis that will be tested in this study is as follows:

H1: The independent board of commissioners has an influence on tax avoidance

Based on the previous study by Fahdilah (2014), it is shown that the audit committee also plays a significant role in terms of legal ways to pay less tax. Relating to the theory and 
the previous research, it is suggested that there is a relation between the audit committee and tax avoidance, which brings up the following hypothesis:

$\mathrm{H} 2$ : The audit committee has an influence on tax avoidance

The companies that are audited by the Public Accountant Firm (KAP) The Big Four usually have good quality audit, which results in the difficulty in doing tax avoidance. Hence, the better the quality of the audit, the fewer tendencies a company have to manipulate the profit of the company in relation to their obligation in taxation (Cai \& Liu, 2009). (Annisa \& Kurniasih, 2012) in her research about the effect of audit quality on tax avoidance finds that there is a significant effect on tax avoidance. Based on this result and on the theory, it is inferred that there is a relation between the quality of the audit and tax avoidance, which creates the following hypothesis

H3: Audit quality has an influence on tax avoidance

As stated by (Eksandy, 2017) research which findings that Audit Committee, Independent Board of Commissioners and Audit Quality together have an effect on tax avoidance.

H4: The Independent Board of Commissioners, Audit Committee and Audit Quality have an influence on tax avoidance

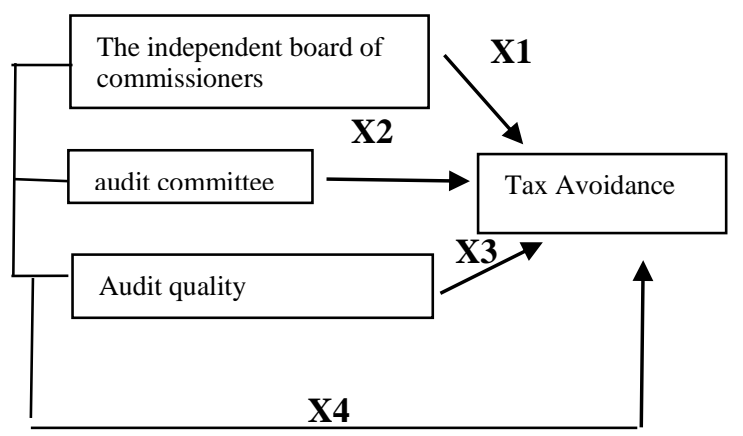

Figure 1. Research Model

\section{METHODS}

This study uses the quantitative technique. The population in this study is the companies that are listed in the IDX. This data collection technique used in this study is the non-probability purposive sampling. The mining companies taken as the samples of this research should have the following criteria:The mining companies are listed in IDX and publish the complete and consistent audited financial report between the years of 2017-2019, the companies are not in the status of suspended or delisting between 2017 and 2019 , the companies have complete data on the research variables, the companies have not suffered any losses from year 2017 to 2019. The category of data used in this study is a secondary data. The secondary data in this study are the financial reports from different mining companies listed in IDX during the period of 2017-2019; the data are taken from IDX official website (www.idx.co.id). This study conducted a normality test dan classic assumption test. The normality test is conducted by doing the One Sample Kolmogarov-Smirnov (K-S) test. The classical assumptions used in this study are: multicollinearity test, heterocedacity test, and autocorrelation test.

The multiple linear regression is used because there is more than one independent variable in this study with the following equation:

$$
\mathrm{Y}=\alpha+\beta 1 \mathrm{X} 1+\beta 2 \mathrm{X} 2+\beta 3 \mathrm{X} 3+\mathrm{e}
$$

\section{RESULTS}

The data for this study is get from the financial reports of the mining corporation listed at IDX between the years 2017 and 2019 and that fulfill the criteria; there are 17 mining companies that fall into the criteria with the total data of 51 financial reports. The data are taken from the websited www.idx.co.id. 
TABLE 1 Normality test

\begin{tabular}{llr}
\hline & & $\begin{array}{c}\text { Unstandardized } \\
\text { Residual }\end{array}$ \\
\hline $\mathrm{N}$ & Mean & 42 \\
\hline Normal & Std. & 0 \\
Parameters $^{\mathrm{a}, \mathrm{b}}$ & Deviation & 0,05762879 \\
\hline Most Extreme & Absolute & 0,103 \\
\cline { 2 - 3 } Differences & Positive & 0,103 \\
\cline { 2 - 3 } & Negative & $-0,088$ \\
\hline Test Statistic & & 0,103 \\
\hline Asymp. Sig. (2-tailed) &, $200^{\mathrm{c}, \mathrm{d}}$ \\
\hline
\end{tabular}

Source: SPSS Processed

The value of the Asymp is sig $0.200>$ $5 \%$, which makes the data normally distributed.

\section{Classic Assumption Test Multicolinearity Test}

TABLE 2. Result of the Multicolinearity Test

\begin{tabular}{lcccccc}
\hline Variabel independen & Tolerance & \multicolumn{2}{c}{ Standar } & VIF Standar & Information \\
& & & & & \\
\hline Independent Board of & 0,928 & 0,10 & 1,077 & 10 & no multi \\
Commissioners & & & & & \\
Audit Committee & 0,880 & 0,10 & 1,136 & 10 & no multi \\
Audit Quality & 0,916 & 0,10 & 1,091 & 10 & no multi
\end{tabular}

Source: SPSS Processed

The Multicolinearity test, as shown in Table 2, appears that the VIF value of all independent variables is less than 10 and the tolerance value is over 0.1 ; hence, a conclusion can be drawn that there is no multikolinearity in the independent variables.

TABLE 3. Result of the Heterocedacity Test

\begin{tabular}{lrc}
\hline Independent Variable & Sig & Information \\
\hline Independent Board of Comm & 0,746 & free from hetero \\
Audit Committee & 0,214 & free from hetero \\
Audit Quality & 0,831 & free from hetero \\
\hline
\end{tabular}

Source: SPSS Processed

Table 3 shows that the Sig value of the Independent Board of Commissioners, Audit
Committee, Audit Quality is which means that the data is free from heterocedacity.

\section{Autocorrelation Test}

TABEL 4 The Result of the Autocorrelation Test

\begin{tabular}{ll}
\hline & $\begin{array}{l}\text { Unstandardized } \\
\text { Residual }\end{array}$ \\
\hline Test Value $^{\mathrm{a}}$ &,- 00792 \\
Cases < Test Value & 21 \\
Cases > Test Value & 21 \\
Total Cases & 42 \\
Number of Runs & 21 \\
Z &,- 156 \\
Asymp.Sig.(2-tailed) &, 876 \\
\hline
\end{tabular}

Source: SPSS Processed

The worth of the Asymp sig is $0.876>$ $5 \%$, which means that the data is free from autocorrelation.

\section{The Statistical Test (t Test)}

TABLE 5. The Result of the $t$ Test

\begin{tabular}{|c|c|c|c|c|c|}
\hline \multicolumn{6}{|c|}{ Coefficients $^{a}$} \\
\hline \multirow[t]{2}{*}{ Model } & \multicolumn{2}{|c|}{$\begin{array}{l}\text { Unstandardized } \\
\text { Coefficients }\end{array}$} & \multirow{2}{*}{$\begin{array}{c}\text { Stand } \\
\text { ardize } \\
d \\
\text { Coeffi } \\
\text { cients } \\
\text { Beta } \\
\end{array}$} & \multirow[t]{2}{*}{$\mathrm{t}$} & \multirow[t]{2}{*}{ Sig. } \\
\hline & $B$ & Std. Error & & & \\
\hline (Constant) & 0,346 & 0,103 & & 3,373 & 0,002 \\
\hline $\begin{array}{l}\text { Independent } \\
\text { Board of } \\
\text { Commisioners }\end{array}$ & 0,086 & 0,038 & 0,317 & 2,232 & 0,032 \\
\hline $\begin{array}{l}\text { Audit } \\
\text { Committee }\end{array}$ & $-0,027$ & 0,03 & $-0,123$ & $9-0,881$ & 0,384 \\
\hline $\begin{array}{l}\text { Audit } \\
\text { Quality }\end{array}$ & $-0,044$ & 0,02 & $-0,303$ & $9-2,162$ & 0,037 \\
\hline
\end{tabular}

Source: SPSS Processed

The Sig value of partially the Independent Board of Commissioners is 0.032 $<5 \%$, which means that there is a partial effect of the Independent Board of Commissioners on TaxAvoidance of $(0.3992 \times 100 \%)$ $15.9201 \%$.

The Sig value of partially the Audit Committee is $0.384>5 \%$, which means that 
there is no partial effect of the Audit Committee on Tax Avoidance.

The Sig Value of partially Audit Quality is $0.037<5 \%$, which means that there is a partial effect of Audit Quality on TaxAvoidance of $(-0.3952 \times 100 \%) 15.6025 \%$.

The regression equation is:

$\mathrm{Y}=0.346+0.086$ the Independent Board of Commissioners - 0.027 Audit Committee - 0.044 Audit Quality

\section{The Statistical Test (F Test)}

TABLE 6. The Result of the F Test

\begin{tabular}{|c|c|c|c|c|c|c|}
\hline \multicolumn{7}{|c|}{ ANOVA $^{a}$} \\
\hline Model & & $\begin{array}{c}\text { Sum of } \\
\text { Squares }\end{array}$ & df & $\begin{array}{l}\text { Mean } \\
\text { Square }\end{array}$ & $\mathrm{F}$ & Sig. \\
\hline & Regression & 0,055 & 3 & 0,018 & 5,086 &, $005^{\mathrm{b}}$ \\
\hline & ${ }^{1}$ Residual & 0,136 & 38 & 0,004 & & \\
\hline & Total & 0,191 & 41 & & & \\
\hline
\end{tabular}

The sig value is found to be $0.005<5 \%$, which means that there is a simultaneous effect of the Independent Board of Commissioners, Audit Committee and Audit Quality on Tax Avoidance.

\section{The Coefficient of Determination}

TABLE 7. The Result of the Coefficient of Determination Test

\begin{tabular}{lll}
\hline $\mathbf{R}$ & R Square & $\begin{array}{c}\text { Adjust } \mathbf{R} \\
\text { Square }\end{array}$ \\
\hline 0,535 & 0,286 & 0,230
\end{tabular}

Source: SPSS Processed

The simultaneous influence of the audit committee, independent board of commissioners and audit quality on tax avoidance is 0.230 or $23 \%$.

\section{DISCUSSION}

The outcome of hypothesis testing express that of the three independent variables, only two variables have an influence on tax avoidance, namely the Independent Board of Commissioners and Audit Quality.
The Infuence of the Independent Board of Commissioners on Tax Avoidance

The hypothesis test express that the effect of the independent board of commissioners on tax avoidance is noteworthy, which shown that the number of the Independent Board of Commissioners played a big role that influenced the tax avoidance behavior of a company. The more independent commissioners there were in a company, the higher the effort to avoid taxation. This result is in line with the found of previous studied by (Alviyani et al., 2016) and (Winata, 2014), which state that the independent board of commissioners played an important role on tax avoidance.

The Effect of Audit Committee on Tax Avoidance

The hypothesis test express that the Audit Committee has no significant influence on tax avoidance. In other words, the number of audit committee has no crucial influence on the tax avoidance behavior of a company. However, the relation between the audit committee on tax avoidance that is not in line also shown that the tendency of avoiding taxation lessens when there are more members in the audit committee. The study did not show a significant effect due to the fact that the audit committee's role in the mining companies is not really effective in dealing with tax avoidance. The result of this study is in line with (Eksandy, 2017) study which found that the audit committee did not influence the tax avoidance behavior.

The Effect of Audit Quality on Tax Avoidance The outcome of the hypothesis test shown that Audit Quality's role on tax avoidance_is significant. This shown that the Public Accounting Firm The Big Four is considered to have more quality compared to non-the big four in terms of auditing the financial reports of a company as they are seen as more capable in limiting the practice of profit management including the tax avoidance in a company. The finding is in line with a previous study on the influence of audit quality on tax avoidance by (Annisa \& 
Kurniasih, 2012), which also express that audit quality played a major role on tax avoidance.

The Effect of the Independent Board of Commissioners, Audit Committee and Audit Quality on Tax Avoidance

The hypothesis test shown that the Independent Board of Commissioners, Audit Committee and Audit Quality have significant influence on tax avoidance. This is in line with (Eksandy, 2017) study which found state that the Independent Board of Commissioners, Audit Committee and Audit Quality simultaneously have an influence on tax avoidance. The simultaneous influence of the independent board of commissioners, audit committee and audit quality on tax avoidance is 0.230 or $23 \%$.

\section{CONCLUSION}

From the discussion above, there are several conclusions that can be drawn from this research:

1. The Independent Board of Commissioners has an effect on tax avoidance. When there are more Independent Commissioners, they will have greater influence on the decision making for tax avoidance for mining companies in Indonesia

2. The Audit Committee has no effect on tax avoidance. This shows that the audit committee does not have any major roles in influencing the decision-making for tax avoidance in the mining companies in Indonesia. The more audit committee there are in a company, the less the tendency for that company to do tax avoidance.

3. Audit Quality has an effect on tax avoidance. If a mining company uses the service of the Public Accounting Firm The Big Four, then they have fewer tendencies to avoid taxation. On the contrary, the companies that do not use the service have a higher tendency in tax avoidance.

4. Simultaneously, the Independent Board of Commissioners, Audit
Committee and Audit Quality have an effect of tax avoidance.

The implications of the research are:

1. The large number of Independent Commissioners will influence aggressive tax decision making.

2. The greater the number of audit committees in a company, the less tax avoidance behavior in that company will be.

3. The company's decision to use the big four public accounting firm will affect the tax avoidance behavior of a company.

4. Companies with good governance are expected to have good tax planning

\section{BIBLIOGRAPHY}

Alviyani, K., Surya, R. A. S., \& Rofika, R. (2016). Pengaruh Corporate Governance, Karakter Eksekutif, Ukuran Perusahaan, Dan Leverage Terhadap Penghindaran Pajak (Tax Avoidance)(Studi Pada Perusahaan Pertanian Dan Pertambangan Yang Terdaftar Di BEI Tahun 2011-2014) Riau University].

Annisa, N. A., \& Kurniasih, L. (2012). Pengaruh corporate governance terhadap tax avoidance. Jurnal akuntansi dan Auditing, 8(2), 123-136.

Aras, G., \& Crowther, D. (2010). Redefining sustainability. A handbook of corporate governance and social responsibility.

Arief, E. (2009). The Power of Good Corporate Governance: Teori dan Implementasi. Salemba Empat, Jakarta.

Cai, H., \& Liu, Q. (2009). Competition and corporate tax avoidance: Evidence from Chinese industrial firms. The Economic Journal, 119(537), 764-795.

Eksandy, A. (2017). Pengaruh komisaris independen, komite audit, dan kualitas audit terhadap penghindaran pajak (tax avoidance)(studi empiris pada sektor 
industri barang konsumsi yang terdaftar di Bursa Efek Indonesia periode 2010-2014). Competitive, 1(1), 1-20.

Hanafi, U., \& Harto, P. (2014). Analisis Pengaruh Kompensasi Eksekutif, Kepemilikan Saham Eksekutif dan Preferensi Risiko Eksekutif Terhadap Penghindaran Pajak Perusahaan. Diponegoro Journal of Accounting, 3(2), 1162-1172.

Hery. (2017). Kajian Riset Akuntansi. Grasindo.

UU No.28 tahun 2007 tentang Perpajakan.

Oktadella, D., \& ZULAIKHA, Z. (2011). Analisis corporate governance terhadap integritas laporan keuangan Universitas Diponegoro].

Pohan, C. A. (2016). Manajemen Perpajakan Strategi Perencanaan Pajak dan Bisnis Edisi Revisi. Jakarta: PT Gramedia Jakarta.

Sandy, S., \& Lukvirman, N. (2015). Pengaruh Corporate Government terhadap Tax Avoidance: Studi Empiris pada Perusahaan Manufakur. 19, 85-98. Retrieved 6 Oktober2020, from https://journal.uii.ac.id/index.php/JAA I/article/view/4328

Subrata, A. (2020). Peran Komisaris Independen di Perusahaan Asuransi. https://icopi.or.id/peran-komisarisindependen-di-perusahaan-asuransi/

Winata, F. (2014). Pengaruh corporate governance terhadap tax avoidance pada perusahaan yang terdaftar di
Bursa Efek Indonesia Tahun 2013. Tax \& Accounting Review, 4(1), 162.

Zain, M. (2008). Manajemen Perpajakan (3 ed.). Salemba Empat.

https://www.idx.co.id 